\title{
The Effect of Nitrogen Gas Flow Rate on the Cr-Containing DLC (Diamond-Like Carbon) Coating by AEGD Hybrid-CVD Coating Process
}

\author{
Yong-Ki Cho' ${ }^{1}$, Jae-Hoon Lee ${ }^{1}$, Masahiro Okumiya ${ }^{2}$, Sang-Gweon Kim ${ }^{1 *}$ \\ ${ }^{1}$ Korea Institute of Industrial Technology, Heat Treatment R \& D Group, Incheon, South Korea \\ ${ }^{2}$ Toyota Technological Institute, Nagoya, Japan \\ Email: *kimsg@kitech.re.kr
}

How to cite this paper: Cho, Y.-K., Lee, J.-H., Okumiya, M. and Kim, S.-G. (2017) The Effect of Nitrogen Gas Flow Rate on the Cr-Containing DLC (Diamond-Like Carbon) Coating by AEGD Hybrid-CVD Coating Process. Advances in Materials Physics and Chemistry, 7, 198-211. https://doi.org/10.4236/ampc.2017.75016

Received: February 21, 2017

Accepted: May 15, 2017

Published: May 18, 2017

Copyright (c) 2017 by authors and Scientific Research Publishing Inc. This work is licensed under the Creative Commons Attribution International License (CC BY 4.0).

http://creativecommons.org/licenses/by/4.0/ c) (†) Open Access

\begin{abstract}
The development of electric and hybrid automobiles has gained momentum with the growth of interest in the field of miniaturization of electrode materials. In particular, technologies that improve the electrical property of stainless steel, while maintaining corrosion resistance, are gaining interest in terms of maintaining specific resistivity. The study on metal doping in diamond-like carbon coating is currently in progress to enhance the characteristics of conductivity and corrosion resistance with excellent properties such as corrosion resistance and lubrication coating. It is the process of using $\mathrm{Cr}$ arc with DLC coating to actuate AEGD. The change of $I(D) / I(G)$ (Graphite peak $(G)$ and disordered bond peak (D)) ratio and G-peak position in Cr-containing DLC film causes graphitization and thus lowers the basic electric resistance. Simultaneous input of nitrogen gas leads to deposition of $\mathrm{CrN}$ by a specific ratio of $\mathrm{Cr}$ and $\mathrm{N}$ in the DLC coating, and the nitrogen atoms replace hydrogen in bonding to increase the $\mathrm{sp}^{3}$ bond structure in the DLC film, in which $\mathrm{CrN}$ is not deposited, to result in specific resistivity of a specific value or less.
\end{abstract}

\section{Keywords}

$\mathrm{Cr}(\mathrm{N})-\mathrm{C}: H$ Film, Nitrogen Doping, Graphitic Carbon, Electrical Resistivity, Plasma CVD, Arc Enhanced Glow Discharge (AEGD)

\section{Introduction}

In response to the demand for lightweight electrode materials and miniaturization of electrode materials, attempts to raise electric efficiency and improve output by using stainless steel sheets instead of graphite materials to reduce resistance against power loss due to the passing of gases, while lowering the volume are being made, and achievements in this field has spurred the develop- 
ment of hybrid automobiles [1] [2] [3].

Diamond-like carbon (DLC) films possess valuable properties, such as smoothness, high lubrication chemical inertness, and extreme hardness. And, it is well known that the a-C:H films fabricated by plasma-enhanced chemical vapor deposition (PECVD) using hydrocarbon sources show very high electrical resistivity of over $10^{8} \Omega$-cm.

Therefore, conductive DLC is emerging as a surface treatment technology that can maintain the corrosion resistance of stainless steel, while maintaining the consistent surface resistance of stainless steel that can be used in PEMFC and separators.

Accordingly, researchers are showing interest in nano-crystalline carbon coating or coating that forms metal and carbide mixtures in many application studies, and research is being conducted on conductive DLC coating [4] [5].

Stainless steel separators have advantages as they are used as electrode materials of automobile fuel cells in terms of anti-corrosiveness, lower gas permeability, flexibility and cost-effectiveness. It has the problem of reduced conductivity due to the thickness of the oxidization layer with self-protective features in the oxidization and corrosive atmosphere that stainless steel is placed in. The interfacial ohmic loss between the metallic separator and membrane electrode decreases the overall power output of PEMFCs due to the corrosion of metallic surface [6] [7].

Among methods, focus fell on nano-crystalline carbon coating due to its chemical inertness and conduction properties that involve metal DLC (Me-C:H) films formed by a hybrid system that compromised between plasma CVD and arc-enhanced glow discharge. Firstly, Ti-containing DLC deposited on stainless steel plates has recorded values of resistivity under $10 \mathrm{~m} \Omega-\mathrm{cm}$. However, Ti-C:H films exhibit insufficient corrosion resistance of over $10 \mu \mathrm{A} / \mathrm{cm}^{2}$ for the passivation region in solutions of sulfuric acid used to simulate the PEMFC environment [8] [9] [10] [11].

The $\mathrm{Cr}-\mathrm{C}: \mathrm{H}$ has excellent resistance against corrosion and therefore displays low corrosion current values even in sulfuric acid solutions. However, $\mathrm{Cr}-\mathrm{C}: \mathrm{H}$, showed poor electrical properties such as having resistance in excess of $10 \mathrm{~m} \Omega-\mathrm{cm}$. Thus, research was conducted on enhancing the two properties of corrosion resistance and specific resistivity using the nitrogen doping technique. This supplied the surplus electrons and increased the density of the current [4] [12].

This study focused on understanding the mechanism of chemical inertness and the electrical resistivity of nitrogen-doped $\mathrm{Cr}-\mathrm{C}: \mathrm{H}$ films deposited by plasma enhanced chemical vapor deposition (PECVD) and arc-enhanced glow discharge (AEGD). With these issues in mind, fabrications of nitrogen-doped Cr$\mathrm{C}: \mathrm{H}$ films and analyses of their characteristics were carried out.

\section{Experimental Procedure}

\subsection{Preparation of $\mathrm{Cr}(\mathrm{N})-\mathrm{C}: \mathrm{H}$ Films}

The fabrication method is a hybrid system of PECVD with AEGD for enhancing 
the plasma state. An anodic electrode is installed on the opposite side of the cathode arc source. A negative arc current is supplied to the cathode target, and a positive voltage is applied to the anode. For metal containing hydrocarbon film deposition, a negative pulsed bias is applied to the substrates in mixed reactive gases. This auxiliary glow discharge method could produce more effective ionization and dissociation caused by the collision of electrons in the plasma. And those ions move onto the substrates which have negative potential. This hybrid system leads to a high energetic collision of excited species on the substrates.

The substrates prepared were type austenitic stainless steel (JIS-SUS316) and a $\mathrm{Si}(100)$ wafer. For the corrosion tests, the stainless steel specimen had a diameter of $15 \mathrm{~mm}$. The substrates were ultrasonically cleaned with acetone and ethanol for $20 \mathrm{~min}$. Before deposition, the substrates were cleaned using Ar plasma for $60 \mathrm{~min}$. Following plasma cleaning, the $\mathrm{Cr}$ interlayer was deposited to improve the adhesion of the films to the substrate.

The $\mathrm{Cr}(\mathrm{N})-\mathrm{C}: \mathrm{H}$ films continued $\mathrm{Cr}$ arc coating to flow the current on the anode electrode in the opposite side of $\mathrm{Cr}$ arc target. Deposition was achieved with a uni-polar pulse plasma $(-800 \mathrm{~V}, 50 \mathrm{kHz}$, duty cycle $70 \%)$. During the arc-enhanced glow discharge, the cathode arc current was $60 \mathrm{~A}$ and the process pressure was $1 \mathrm{~Pa}$. The anode electrode current was $30 \mathrm{~A}$. The shutter was installed in front of the arc target to prevent contamination of the film by micro and macro particles.

At the same time, amounts of the $\mathrm{Ar}$ is $40 \mathrm{sccm}, \mathrm{CH}_{4}$ is $120 \mathrm{sccm}$, and $\mathrm{N}_{2}$ is 0 $60 \mathrm{sccm}$ gases were supplied according to the relevant variable.

The deposition rate of $\mathrm{Cr}(\mathrm{N})-\mathrm{C}: \mathrm{H}$ films were a slight decline with increase of nitrogen gas flow rate in Figure 1, (a) is $810 \mathrm{~nm} / \mathrm{h}$ at $\mathrm{N}_{2} 0 \mathrm{sccm}$, (b) is $803 \mathrm{~nm} / \mathrm{h}$ at $\mathrm{N}_{2} 20 \mathrm{sccm}$, (c) is $644 \mathrm{~nm} / \mathrm{hat} \mathrm{N}_{2} 40 \mathrm{sccm}$ and (d) is $540 \mathrm{~nm} / \mathrm{hat} \mathrm{N}_{2} 60 \mathrm{sccm}$.

Since the deposition thickness varied according to amount of added nitrogen along with Figure 1, it was set to form $1 \mu \mathrm{m}$ thick coating and it was formed at 60 - 90 minutes. The substrate temperature rose to $150^{\circ} \mathrm{C}$ during deposition.

Experimental details are shown in Table 1.

Table 1. Coating variable.

\begin{tabular}{cc}
\hline Event & Values \\
Pressure & $1 \mathrm{~Pa}$ \\
Ar flow rate & $40 \mathrm{sccm}$ \\
$\mathrm{CH}_{4}$ flow rate & $120 \mathrm{sccm}$ \\
$\mathrm{N}_{2}$ flow rate & $0-60 \mathrm{sccm}$ \\
Temperature & $\leq 150^{\circ} \mathrm{C}$ \\
Arc cathode current & $60 \mathrm{~A}$ \\
Additional anode current & $30 \mathrm{~A}$ \\
Substrate bias voltage & $-800 \mathrm{~V}$ \\
Duty cycle & $70 \%$ (unipolar) \\
Frequency & $50 \mathrm{kHz}$ \\
Time (min) for $1 \mu \mathrm{m}$ & $60-90$ \\
\hline
\end{tabular}




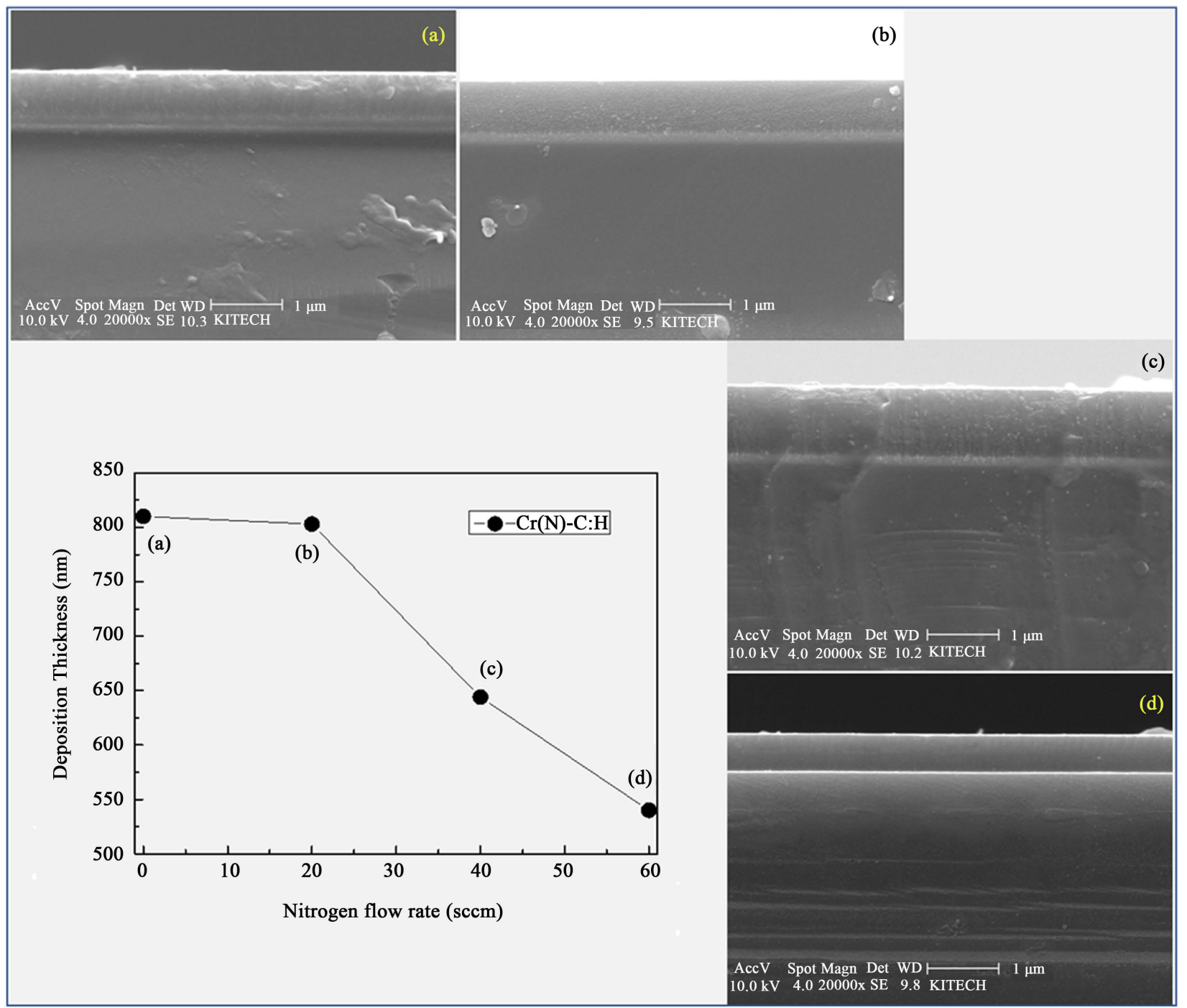

Figure 1. Deposition thickness of $\mathrm{Cr}(\mathrm{N})-\mathrm{C}: \mathrm{H}$ films according to the change in the amount of nitrogen gas flow rate.

\subsection{Characterization of $\mathrm{Cr}(\mathrm{N})-\mathrm{C}: \mathrm{H}$ Films}

The specific resistance was measured by a four-point probe (CMT-SR1000N). To determine the corrosion resistance of the films, the potentio-dynamic polarization was measured in a hydrogen-blown solution of 1 mole of $\mathrm{H}_{2} \mathrm{SO}_{4}$ containing $2 \mathrm{ppm}$ fluorine at $80^{\circ} \mathrm{C}$. The chemical compositions and bonding states of the $\mathrm{Cr}(\mathrm{N})-\mathrm{C}: \mathrm{H}$ films were analyzed by $\mathrm{X}$-ray photoelectron spectroscopy (Multilab 2000, Thermo) with a monochromatic Al ka X-ray radiation (1486.7 eV) and Raman spectroscopy (LabRamHR) equipped with an Ar laser with a wavelength of $514.4 \mathrm{~nm}$. The deposition rate and surface morphology of the films were determined by scanning electron microscopy (SIRION-400). The micro structure of the films was examined by the XRD with a $1.540 \AA$ Cuka line and diffractometer system (X'PERT-PRO).

\section{Results and Discussion}

The fabrication of nitrogen-doped $\mathrm{Cr}-\mathrm{C}: \mathrm{H}$ films was carried out by the variation 
of the partial pressure of nitrogen controlled by nitrogen flow rates from zero to $60 \mathrm{sccm}$, when the working pressure was kept at $1 \mathrm{~Pa}$. As shown in Figure 2(a) and Figure 2(b), the $\mathrm{Cr}-\mathrm{C}: \mathrm{H}$ film and $\mathrm{Cr}(\mathrm{N})-\mathrm{C}: \mathrm{H}$ film doped with a nitrogen concentration of 6.1at.\% showed excellent properties for corrosion in potentiodynamic polarization tests in sulfuric acid. The Cr-C:H film showed corrosion resistance superior to bare stainless steels, as shown in Figure 1(a). The lowconcentration nitrogen-doped $\mathrm{Cr}(\mathrm{N})-\mathrm{C}: \mathrm{H}$ film also exhibited high corrosion resistance below $1 \mu \mathrm{A} / \mathrm{cm}^{2}$ in the passivation region (Figure $2(\mathrm{~b})$ ). However, as the concentration of nitrogen increased, corrosion resistance reduced.

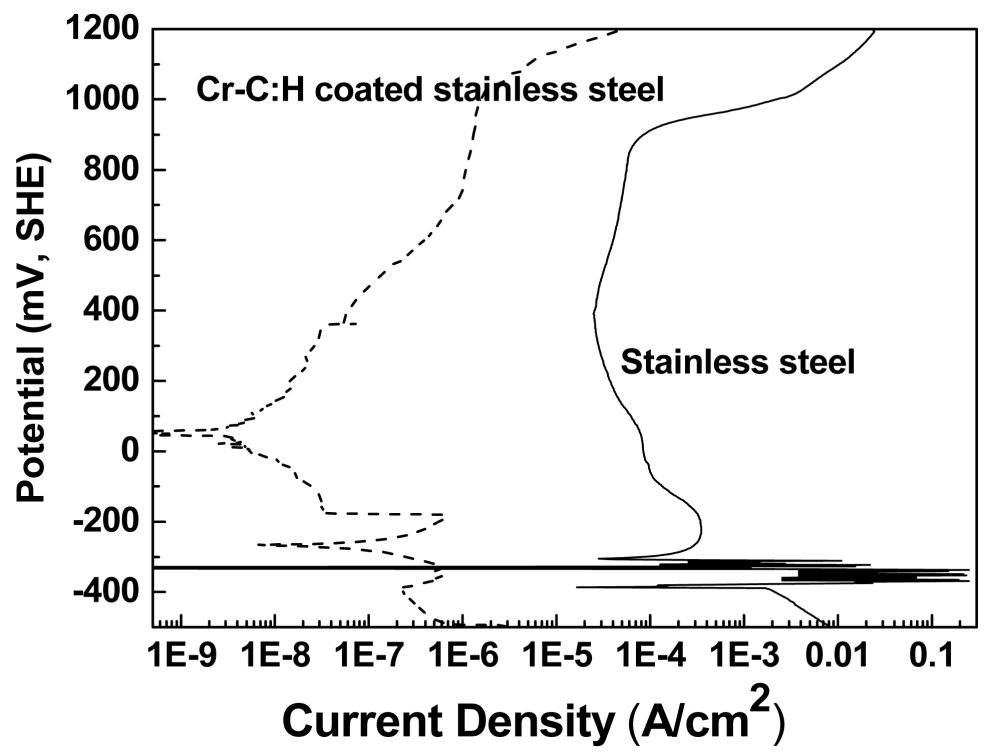

(a)

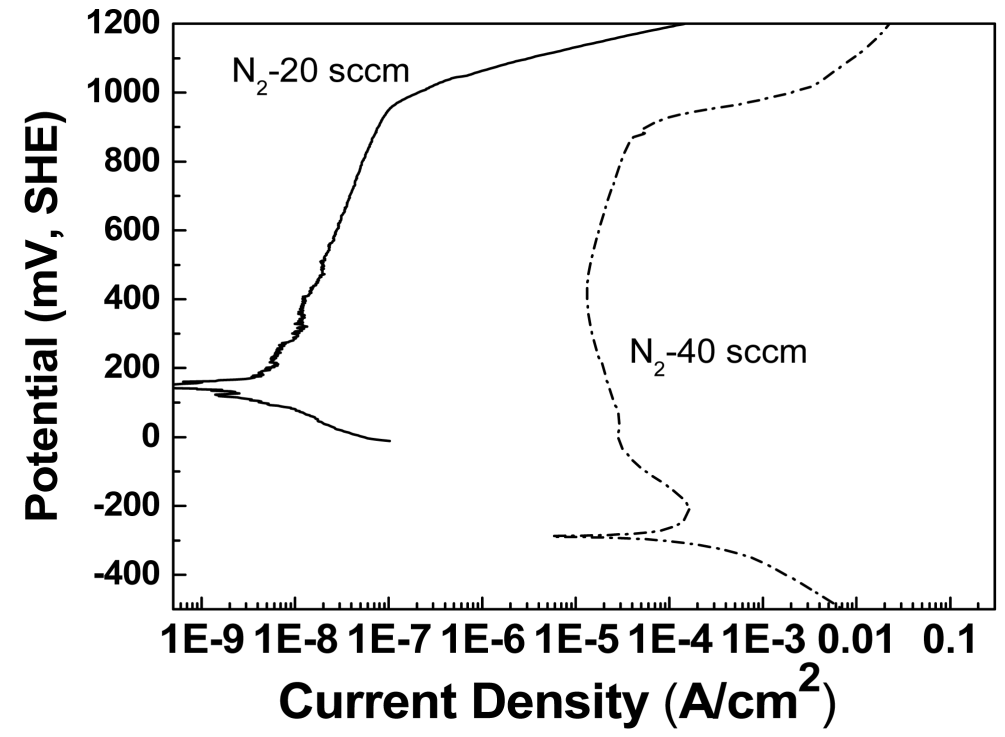

(b)

Figure 2. Potentio-dynamic corrosion test results of $\mathrm{Cr}-\mathrm{C}: \mathrm{H}$ films formed according to the change in the amount of nitrogen gas flow rate. (a) Corrosion behavior of raw materials (stainless steel) and $\mathrm{Cr}-\mathrm{C}: \mathrm{H}$ film; (b) Corrosion behavior of $\mathrm{Cr}-\mathrm{C}: \mathrm{H}$ film according to change of nitrogen gas flow rate. 
To explain this phenomenon, we examine the chemical bonding structure of the films. Table 2 shows the chemical compositions of the films determined by XPS analysis. As nitrogen concentrations increased to over 10 at $\%$ in the films, the anti-corrosiveness of the $\mathrm{Cr}(\mathrm{N})-\mathrm{C}: \mathrm{H}$ films decreased by $\mathrm{N}_{2} 40 \mathrm{sccm}$ as shown in Figure 2(b). In contrast, the carbon concentrations decreased from 95 to 84 at $\%$ with varying nitrogen gas flow rate.

In addition, depending on the change of concentration of nitrogen gas, there was a phenomenon where the components of $\mathrm{Cr}$ and $\mathrm{O}$ would change within $\mathrm{Cr}-\mathrm{C}: \mathrm{H}$. When the nitrogen gas content was doped in excess of $40 \mathrm{sccm}$ in the process, nitrogen concentration within the $\mathrm{Cr}-\mathrm{C}: \mathrm{H}$ film was 10 at\%, $\mathrm{Cr}$ was 10 at $\%$, and $\mathrm{O}$ was 2.4 at $\%$, showing the chemical make-up ratio of each element.

In this study, Figure 3 shows to the saturation phenomenon in the specific resistivity measurement value from the four-point probe according to nitrogen gas concentration. Likewise, it is shown in Figure 4 that it is proportional to the change curve of $\mathrm{C}-\mathrm{N}, \mathrm{C}=\mathrm{N}$ ratio. The goal for electrical resistivity in the $\mathrm{Cr}-\mathrm{C}: \mathrm{H}$ film was not reached.

However, as $\mathrm{Cr}-\mathrm{C}: \mathrm{H}$ films were doped by nitrogen, electrical resistivity dramatically decreased.

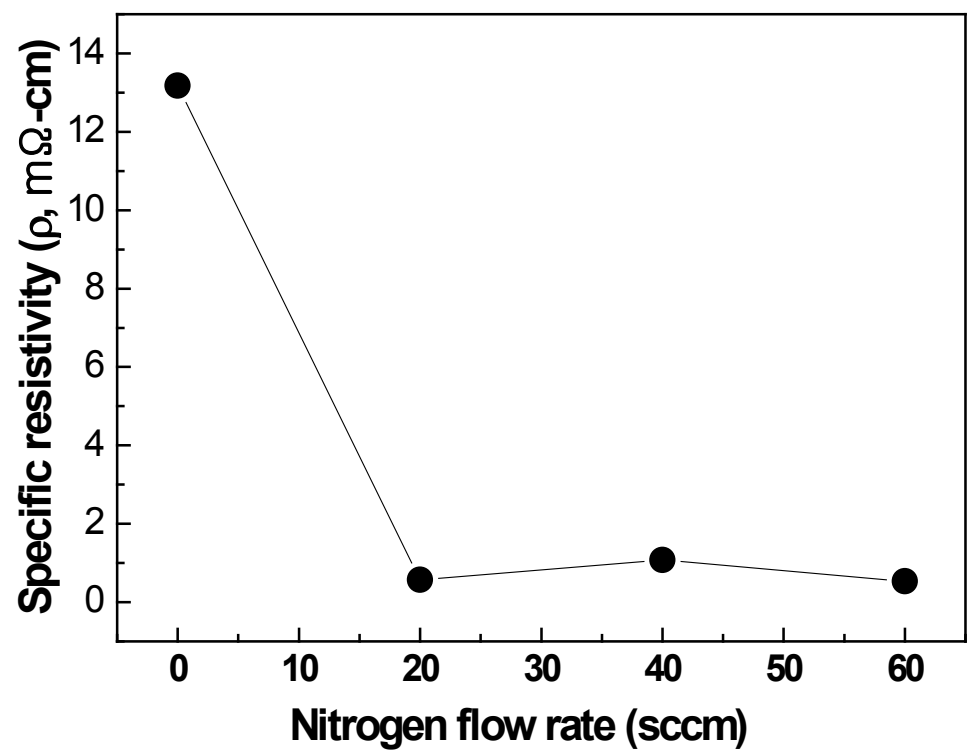

Figure 3. Change of the specific resistivity of $\mathrm{Cr}-\mathrm{C}: \mathrm{H}$ films formed according to the change in nitrogen gas flow rate.

Table 2. Chemical composition of $\mathrm{Cr}-\mathrm{C}: \mathrm{H}$ films depending on nitrogen flow rate.

\begin{tabular}{ccccc}
\hline \multirow{2}{*}{ Nitrogen flow rate $(\mathrm{sccm})$} & \multicolumn{4}{c}{ Chemical compositions (at.\%) } \\
\cline { 2 - 5 } & $\mathrm{C}$ & $\mathrm{N}$ & $\mathrm{Cr}$ & $\mathrm{O}$ \\
\hline 0 & 95.4 & 0 & 3.3 & 1.3 \\
20 & 90.0 & 6.1 & 2.2 & 1.7 \\
40 & 84.5 & 10.2 & 3.4 & 1.9 \\
60 & 84.0 & 10.0 & 3.6 & 2.4 \\
\hline
\end{tabular}




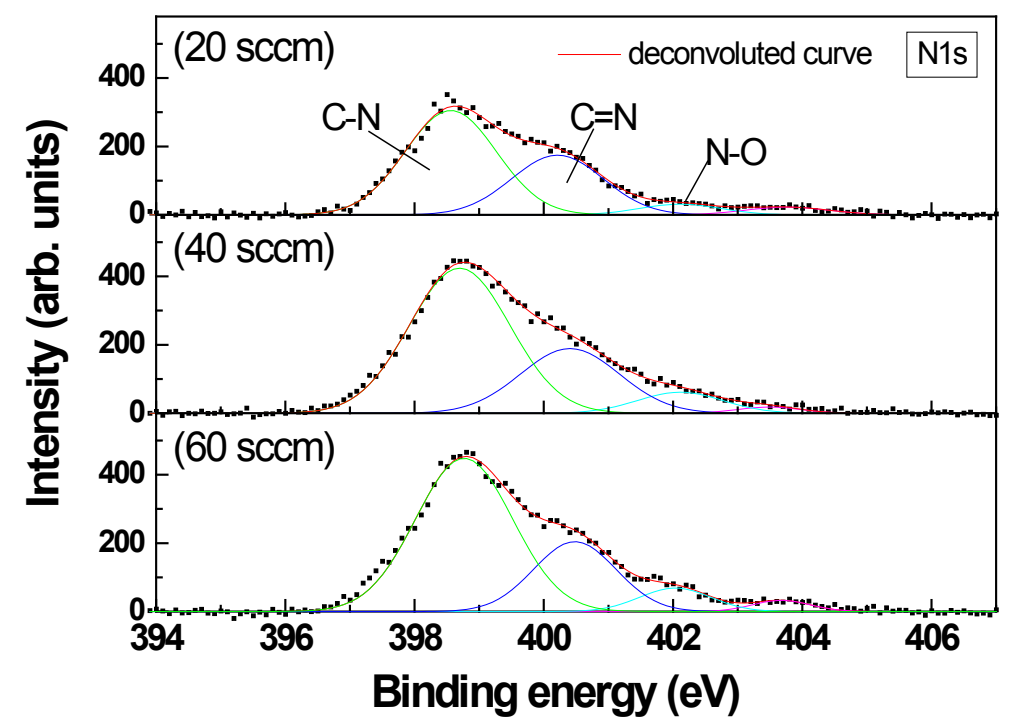

(a)

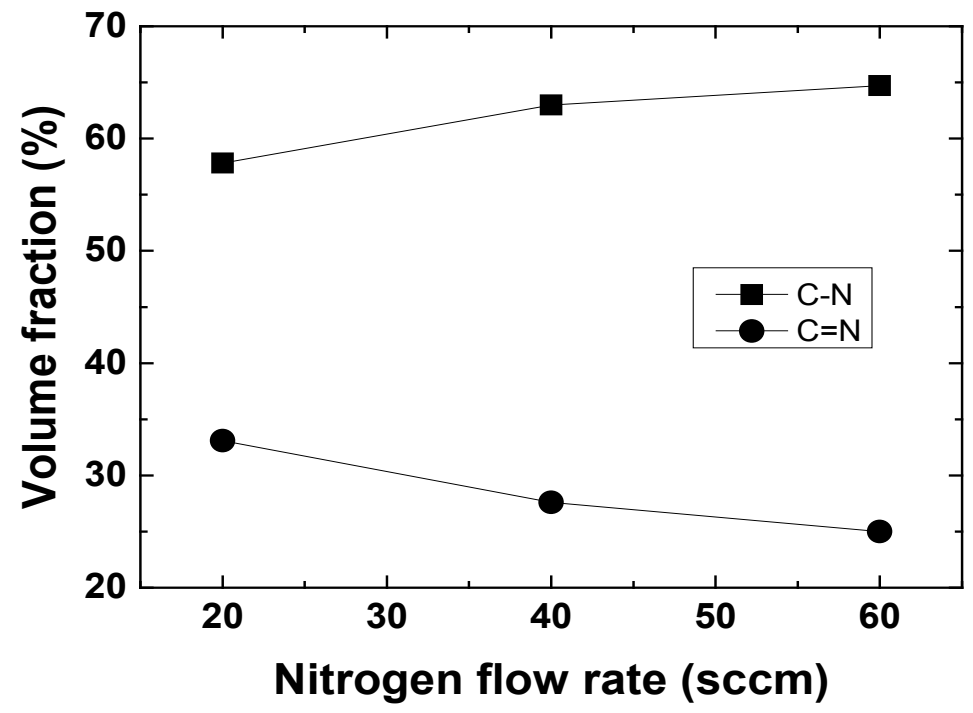

(b)

Figure 4. Nitrogen carbide ratio in $\mathrm{Cr}-\mathrm{C}: \mathrm{H}$ films formed according to change in nitrogen gas flow rate. (a) Fitting of N1s peaks; (b) Volume fraction of N1s peak for C-N (398.7 $\mathrm{eV})$ and $\mathrm{C}=\mathrm{N}(400.5 \mathrm{eV})$.

Figure 3 shows the specific resistance of the $\mathrm{Cr}(\mathrm{N})-\mathrm{C}: \mathrm{H}$ film. The specific resistance was measured below $1 \mathrm{~m} \Omega-\mathrm{cm}$ at a nitrogen flow rate of $20 \mathrm{sccm}$ using the four point probe.

There is a case of measuring the $\mathrm{Cr}-\mathrm{C}: \mathrm{H}$ film with the Cathodic-arc activated deposition (CAAD) method while adding the nitrogen and hydrocarbon gas $\left(\mathrm{C}_{2} \mathrm{H}_{2}\right)$ in varying ratios. This test reported that the content of the sp3 C-N bond and the $\mathrm{sp}^{2} \mathrm{C}=\mathrm{N}$ bond in the $\mathrm{Cr}-\mathrm{C}: \mathrm{H}$ film was low except when the ratio of nitrogen in the additive was high.

On the other hand, the a-C:H film containing nitrogen $(\mathrm{N})$ is well known to be highly conductive because of extra electrons. However, the film stability is low because of poor corrosion resistance [13]. 
The PECVD-AEGD hybrid coating method used in this study ensures that $\mathrm{Cr}$ is contained in the DLC coating quickly using PECVD and arc coating. Moreover, the study selected the process using additional anode electrode to easily form $\mathrm{C}-\mathrm{N}$ and $\mathrm{C}=\mathrm{N}$ bonds in the coating layer through atomization of $\mathrm{N}_{2}$ with high ionization energy.

The specific resistivity dramatically decreased following the addition of nitrogen compared with the $\mathrm{Cr}-\mathrm{C}: \mathrm{H}$ films $(13 \mathrm{~m} \Omega-\mathrm{cm})$. While there are tendencies for corrosion resistance to rise through chromium coating as an outcome of $\mathrm{Cr}-\mathrm{C}: \mathrm{H}$ coating, it has very high the specific resistivity.

However, changes in resistivity were observed when adding in crystalloid through the ionization of nitrogen during arc-ionized chromium coating and electric current flow with AEGD which came as a solution to the problem of conductivity.

The AEGD coating is the process used to reduce the coating period by rapidly increasing the temperature of large metallic material.

Using the AEGD method, different shapes of electrode are fabricated according to purpose and applied in process systems.

This study used an auxiliary electrode to apply the high current of around 30A for ionization of gas around the coating test piece to ionize the nitrogen gas the ionization of which is difficult.

In Figure 4(a), The N1s peaks of the $\mathrm{Cr}(\mathrm{N})-\mathrm{C}: \mathrm{H}$ films were fitted to the $\mathrm{C}-\mathrm{N}$ (398.7 eV), $\mathrm{C}=\mathrm{N}(400.5 \mathrm{eV})$, and $\mathrm{N}-\mathrm{O}(402.1 \mathrm{eV})$ bonds. Among them in Figure 4(b), Carbon and nitrogen bonds were related to the electrical properties due to the C-N peak volume fractions that were similarly increased [14] [15]. At this moment, $\mathrm{C}=\mathrm{N}$ fractions decreased. Following the increase in the partial pressure of nitrogen, the $\mathrm{C}-\mathrm{N}$ bond fraction increased. This was caused by nitrogen combining with carbon in the hydrocarbon matrix. The surplus electrons in the C-N bond act as donors in the carbon matrix. They subsequently charge carriers formed in the film and decrease the specific resistivity by $\mathrm{N}_{2} 40 \mathrm{sccm}$ below.

As shown by the Raman spectra in Figure 5(a), the D-peak of the $\mathrm{Cr}(\mathrm{N})-\mathrm{C}: \mathrm{H}$ films in which the partial pressure of nitrogen was showed slightly difference as a result of the increase in nitrogen concentrations. Figure 5(b) shows that the positions of G-peaks were about $1565 \mathrm{~cm}^{-1}$, with slight shift towards a higher wave number. The D-peak's intensity to G-peak's intensity $(\mathrm{I}(\mathrm{D}) / \mathrm{I}(\mathrm{G}))$ ratios increased from 0.7 to 1.3 . In relation to the $\mathrm{Cr}(\mathrm{N})-\mathrm{C}: \mathrm{H}$ films, the G-peak position and the $\mathrm{I}(\mathrm{D}) / \mathrm{I}(\mathrm{G})$ ratio changed as a result of the increase in nitrogen concentrations in the hydrocarbon matrix. Raman spectroscopy studies of $\mathrm{Cr}-\mathrm{C}: \mathrm{H}$ films have shown that G-peaks shift slightly toward a higher wave number and that the $\mathrm{I}(\mathrm{D}) / \mathrm{I}(\mathrm{G})$ ratio increases in accordance with the rise in the number. This means that the disordered carbon clustering in the films increases with nitrogen doping [16] [17] [18].

Also, it is consistent with the G-peak position value of Figure 5, indicating that nitrogen gas in excess of a certain level is not involved in the $\mathrm{Cr}-\mathrm{C}: \mathrm{H}$ membrane structure. One of the reasons is that the Me-C:H films are filled by graphitic carbon and metal composites. The graphitic carbons are conductors due 


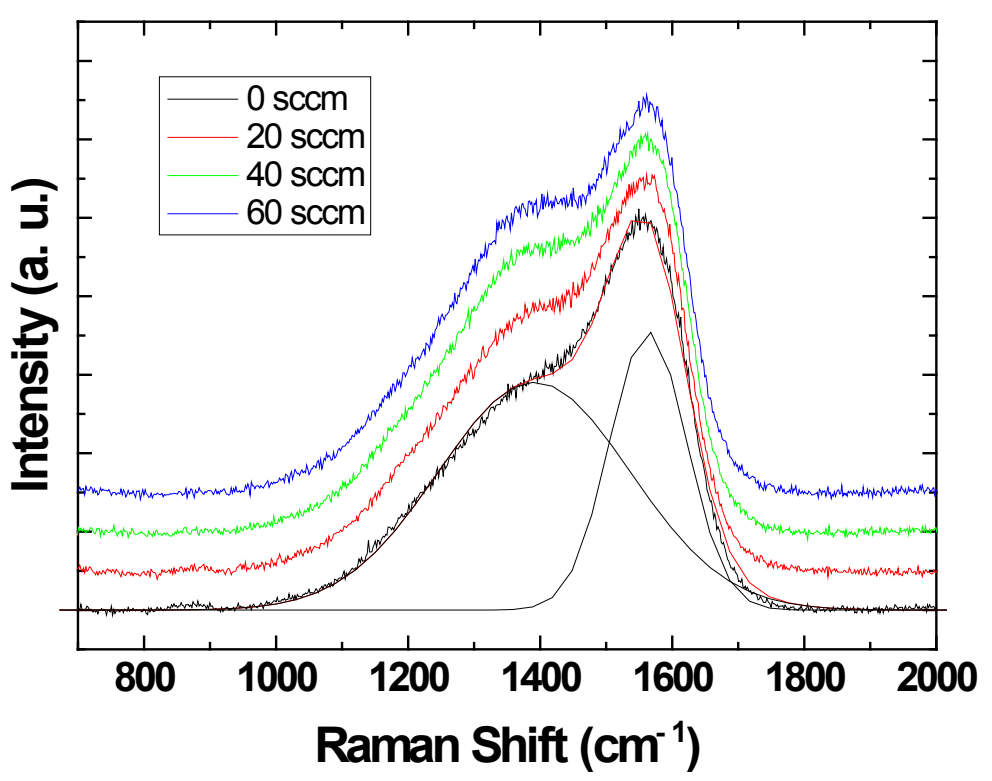

(a)

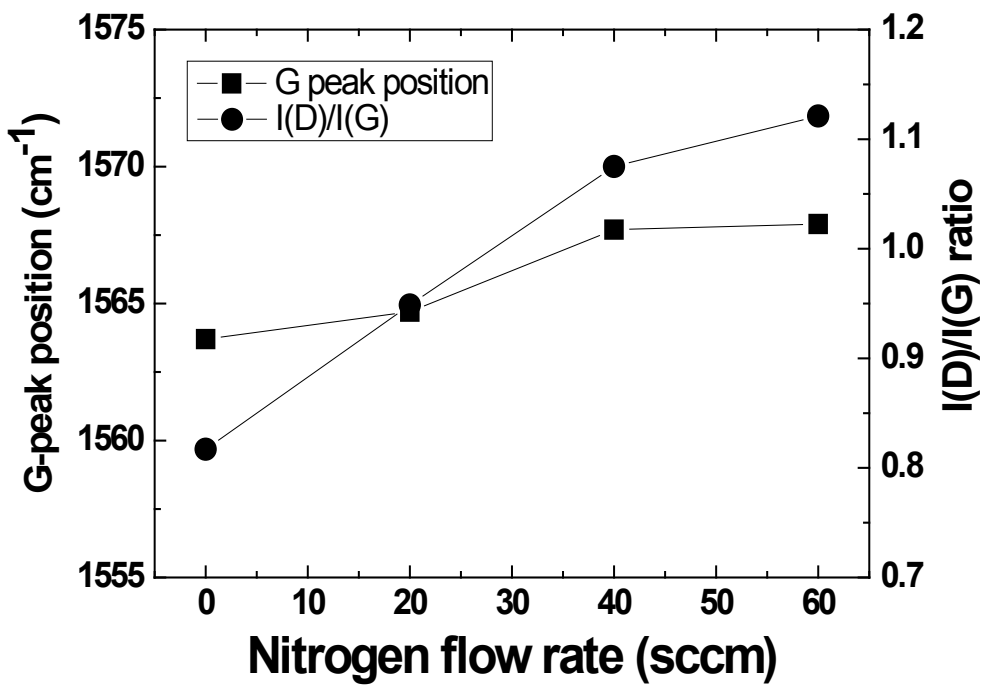

(b)

Figure 5. Raman spectroscopy analysis results in $\mathrm{Cr}-\mathrm{C}: \mathrm{H}$ films formed according to changes in nitrogen gas flow rate. (a) Typical Raman spectrum and Gaussian fitting; (b) G-peaks position and $\mathrm{I}(\mathrm{D}) / \mathrm{I}(\mathrm{G})$ ratio.

to hopping in the $\pi$ state by the carriers. The metal or composite are intrinsic conductive materials. Since these types of materials connect to each other, carriers in films move well which is known as percolation. However, this specific resistivity is limited. But with the introduction of nitrogen in the films, the resistivity was dramatically decreased. This phenomenon cannot be clearly explained by the percolation theory. So, we propose that the surplus electrons of carbon and nitrogen bonds could be responsible for the conduction.

For more detailed investigation of the corrosion characteristics, C1s peaks were deconvoluted by the Gaussian multi-curve fitting in Figure 6(a). The $\mathrm{sp}^{2}$ $(284.5 \pm 0.1 \mathrm{eV})$ and $\mathrm{sp}^{3}(285.2 \pm 0.1 \mathrm{eV})$ bonds were mainly fitted. In addition, 


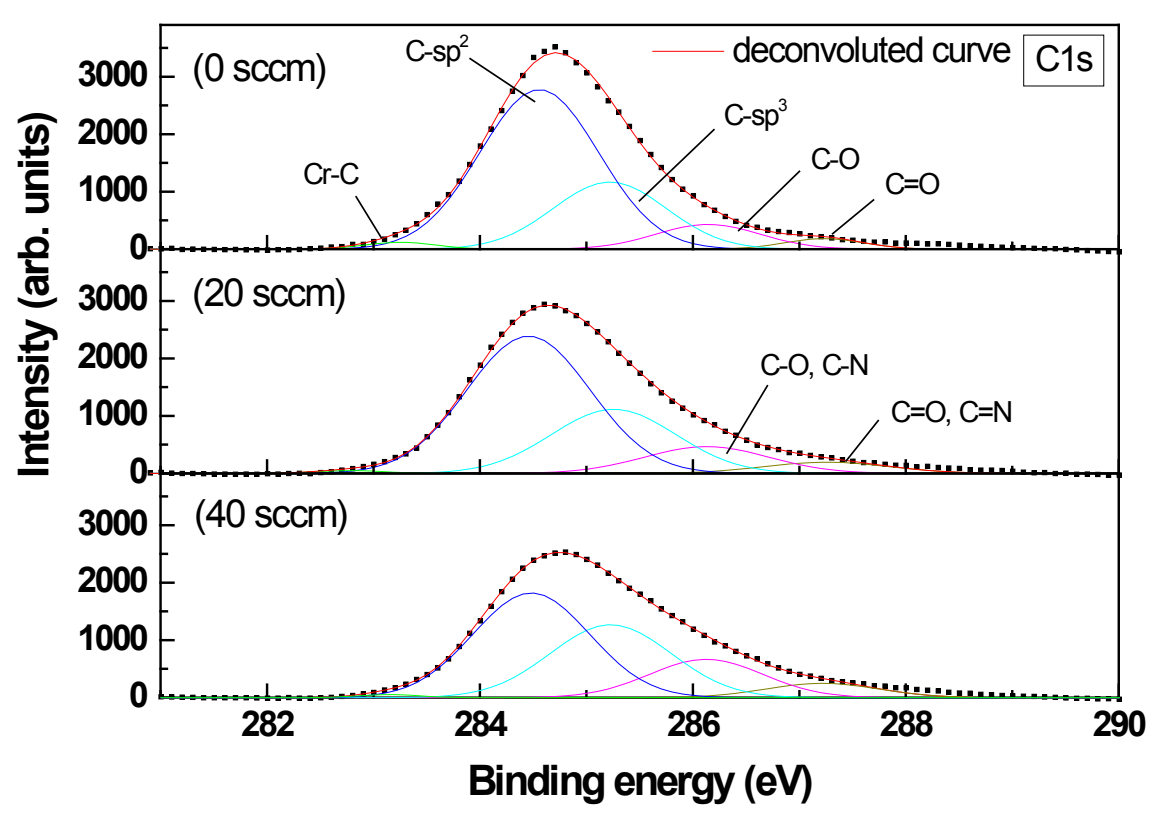

(a)

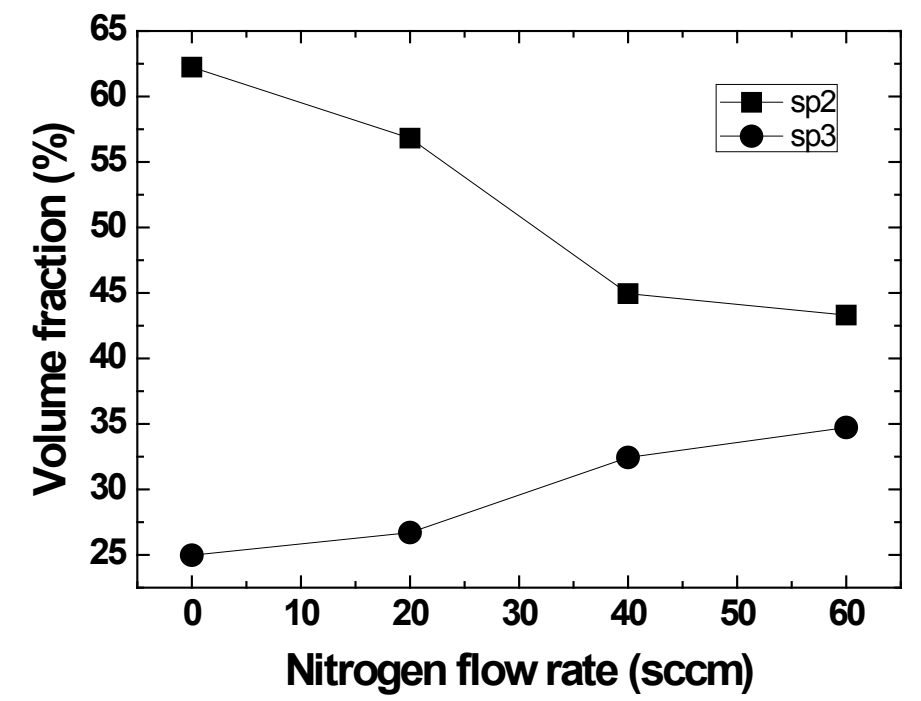

(b)

Figure 6. Structural changes of carbon in $\mathrm{Cr}-\mathrm{C}: \mathrm{H}$ films formed according to changes in nitrogen gas flow rate. (a) Fitting curve of C1s peaks; (b) Volume fraction of C1s peak for $\mathrm{sp}^{2}(284.5 \mathrm{eV})$ and $\mathrm{sp}^{3}(285.2 \mathrm{eV})$.

C-CO $(285.2 \pm 0.1 \mathrm{eV}), \mathrm{C}-\mathrm{O} / \mathrm{C}-\mathrm{N}$ bonds $(286.1 \pm 0.3 \mathrm{eV})$, and $\mathrm{C}=\mathrm{O} / \mathrm{C}=\mathrm{N}$ bonds $(287.2 \pm 0.1 \mathrm{eV})$ were present in the $\mathrm{Cr}(\mathrm{N})-\mathrm{C}: \mathrm{H}$ films [9] [10]. However, the metallic carbide peak as $\mathrm{Cr}-\mathrm{C}$ bonds $(283.2 \pm 0.1 \mathrm{eV})$ was very small.

Figure $6(\mathrm{~b})$ shows the volume fraction of $\mathrm{sp}^{2}$ and $\mathrm{sp}^{3}$ bond of $\mathrm{C} 1 \mathrm{~s}$ peaks. The volume fraction analysis revealed that the $\mathrm{sp}^{2}$ carbon bond fraction decreased from $62 \%$ to $43 \%$ when the nitrogen concentrations increased. The $\mathrm{sp}^{3}$ bond fraction increased from $25 \%$ to $35 \%$ in the same conditions. Through the analysis of $\mathrm{C} 1 \mathrm{~s}$ peaks, for a volume fraction of $\mathrm{sp}^{2}$ bond of over $56 \%$, the corrosion resistance was high but decreasing $\mathrm{sp}^{2}$ bond and increasing $\mathrm{sp}^{3}$ bond reduced the anti-corrosion property. 
The $\mathrm{Cr}-\mathrm{C}: \mathrm{H}$ films consisted of noble graphitic carbon, anti-corrosive hydrocarbon, and a smaller amount of chromium incorporated into the carbon matrix. We thought that the presence of graphite-like carbon such as $\mathrm{sp}^{2}$ bond mainly contributed to reducing galvanic corrosion. Also, incorporation of chromium in the matrix decreased the corrosiveness. The incorporation of metal in the carbon matrix prevented the dissolution of metals and charge exchanges from the surface in a corrosive atmosphere [19]. The noble graphitic carbon and incorporation of metals in the films enhanced the chemical stability as the corrosion potential moves positive by restriction of galvanic corrosion under electrochemical reaction.

By the Gaussian fitting of $\mathrm{Cr} 2 \mathrm{p} 1$ and $\mathrm{Cr} 2 \mathrm{p} 3$ peaks, chromium, chromium nitride, and chromium oxide were detected in the films. In the $\mathrm{Cr}-\mathrm{C}: \mathrm{H}$ films, chromium mainly remained in the metallic state and not as metal composites. The low-concentration doped $\mathrm{Cr}-\mathrm{C}: \mathrm{H}$ film showed a metal-rich state and highconcentration doped $\mathrm{Cr}-\mathrm{C}: \mathrm{H}$ films were changed to chromium-nitride-rich films.

In Figure 2(b), the nitrogen concentration of 6.1-at.\%-doped $\left(\mathrm{N}_{2} 20 \mathrm{sccm}\right)$ $\mathrm{Cr}(\mathrm{N})-\mathrm{C}: \mathrm{H}$ films showed a high corrosion resistance, and that of the high- concentration doped films were reduced. This increasing corrosiveness at highconcentration nitrogen concentrations of over 10 at $\%$ were related to the decreasing $\mathrm{sp}^{2}$ volume fraction. The increasing $\mathrm{sp}^{3}$ bond was caused by $-\mathrm{C}-\mathrm{C}: \mathrm{H}$ or -C-C:N species and the formation of composites such as carbide, nitride, and oxide in films. Through nitrogen doping, the $\mathrm{sp}^{3}$ bonds increase, and the appearance of chromium composites in the films deteriorated the corrosion properties.

These explanations for the corrosion behavior are not exact with regard to the role of metal and graphitic carbon. Further research on the role played in corrosion by graphitic carbon and metal incorporation is needed.

Figure 7 shows the XRD pattern of the films with varying nitrogen flow rates. The presence of amorphous structure at low partial pressure of nitrogen in the gas mixture means that chromium retained metallic incorporation or nano-sized polycrystalline composites in the matrix. However, when the nitrogen flow rate surpassed $40 \mathrm{sccm}$, nitride and chromium oxide were present at low concentrations in the $\mathrm{Cr}(\mathrm{N})-\mathrm{C}: \mathrm{H}$ films.

According to the composition in Table 2, there was no significant change in XRD analysis when the Cr:N ratio was less than 1:2.77. However, XRD deposition was visible when the Cr:N ratio was 1:3 in the case of $\mathrm{N}_{2} 20 \mathrm{sccm}$. In that case, the corrosion resistance deteriorated when the deposition was visible even at the corrosion potential value in Figure 2(b).

The experimental consequence of this study led ionization of $\mathrm{Cr}$ arc coating process and increased rate of graphitization in the DLC film by applying the high energy by AEGD to $\mathrm{Cr}$ ions at the same time. As the result, the specific resistivity decreased from about $13 \mathrm{~m} \Omega$ level to below $1 \mathrm{~m} \Omega$ level as shown in $\mathrm{N}_{2} 0$ sccm in Figure 3. While the addition of nitrogen affected the change of $\mathrm{I}(\mathrm{D}) / \mathrm{I}(\mathrm{G})$ ratio, it contributed to the increased $\mathrm{sp}^{3}$ structure of nitrogen bonding 


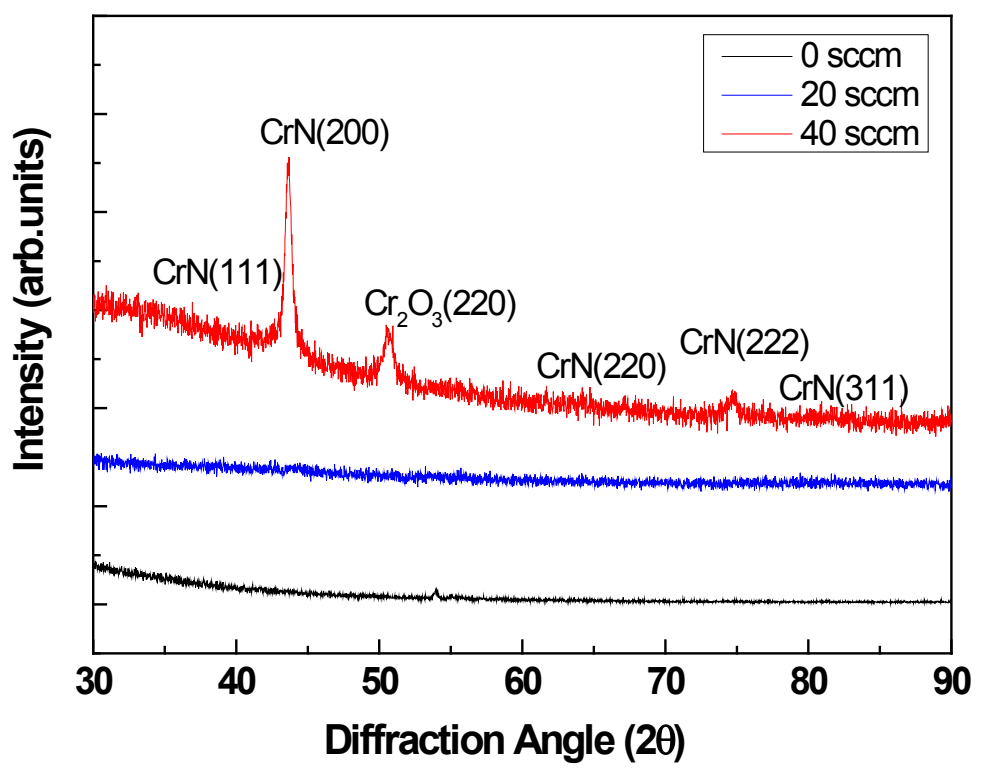

Figure 7. Changes in X-ray diffraction patterns of $\mathrm{Cr}-\mathrm{C}: \mathrm{H}$ films formed according to nitrogen gas flow rate.

in the position of hydrogen, i.e. transformation of $-\mathrm{C}-\mathrm{C}-\mathrm{H}$ to $-\mathrm{C}-\mathrm{C}-\mathrm{N}$, more than the electric resistance of graphitization DLC film formed through high energy $\mathrm{Cr}$ ionization by AEGD.

\section{Conclusions}

1) The $\mathrm{Cr}(\mathrm{N})-\mathrm{C}: \mathrm{H}$ was formulated using a hybrid method of PECVD and AEGD. Although the graphitization, which is the process of high energy $\mathrm{Cr}$ by arc and AEGD affecting the coating film to increase the $\mathrm{I}(\mathrm{D}) / \mathrm{I}(\mathrm{G})$ ratio, significantly affected the increase of electric conductivity and affected the increase of $\mathrm{I}(\mathrm{D}) /$ $\mathrm{I}(\mathrm{G})$ ratio when the nitrogen existed in the $\mathrm{sp}^{3}$ structure, the electric conductivity saturated to a specific value.

2) The Cr- $\mathrm{C}: \mathrm{H}$ film that does not contain nitrogen gas showed outstanding corrosion resistance compared to the stainless steel raw material. However, the $\mathrm{Cr}-\mathrm{C}: \mathrm{H}(\mathrm{N})$ film that was formed according to the nitrogen gas content rapidly lowered the specific resistivity value, and the cluster form in the $\mathrm{I}(\mathrm{D}) / \mathrm{I}(\mathrm{G})$ ratio was observed according to nitrogen content. The XPS analysis confirmed that the significant amount of $\mathrm{sp}^{3} \mathrm{C}-\mathrm{N}$ bond and $\mathrm{sp}^{2} \mathrm{C}=\mathrm{N}$ bond is formed in the film.

3) While the deposition, the $\mathrm{CrN}$ phase was invisible in $\mathrm{X}$-ray diffraction pattern when the $\mathrm{Cr}: \mathrm{N}$ ratio was 1:2.77 or less, it was visible when the ratio was 1:3. In that case, there was decrease of the specific resistivity and increase of the corrosion current simultaneously. As the result of such formation, the electric resistance rapidly decreased at $20 \mathrm{sccm}$ of $\mathrm{N}_{2}$ gas and then was saturated at 40 and $60 \mathrm{sccm}$.

\section{References}

[1] Pozio, A., Zaza, F., Masci, A. and Silva, R.F. (2008) Bipolar Plate Materials for 
PEMFCs: A Conductivity and Stability Study. Journal of Power Sources, 179, 631639.

[2] Fu, Y., Lin, G., Hou, M., Wu, B., Li, H., Hao, L., Shao, Z. and Yi, B. (2009) Optimized Cr-Nitride Film on 316L Stainless Steel as Proton Exchange Membrane Fuel Cell Bipolar Plate. International Journal of Hydrogen Energy, 34, 453-458.

[3] Show, Y., Miki, M. and Nakamura, T. (2007) Increased in Output Power from Fuel Cell Used Metal Bipolar Plate Coated with a-C Film. Diamond and Related Materials, 16, 1159-1161.

[4] Corbella, C., Oncins, G., Gomez, M.A., Polo, M.C., Pascual, E., Garcia-Cespedes, J., Andujar, J.L. and Bertran, E. (2005) Structure of Diamond-like Carbon Films Containing Transition Metals Deposited by Reactive Magnetron Sputtering. Diamond and Related Materials, 14, 1103-1107.

[5] Staryga, E. and Bak, G.W. (2005) Relation between Physical Structure and Electrical Properties of Diamond-Like Carbon Thin Films. Diamond and Related Materials, 14, 23-34.

[6] Tawfik, H., Hung, Y. and Mahajan, D. (2007) Metal Bipolar Plates for PEM Fuel Cell-A Review. Journal of Power Source, 163, 755-767.

[7] Ren, Y.J. and Zeng, C.L. (2007) Corrosion Protection of 304 Stainless Steel Bipolar Plates Using TiC Films Produced by High-Energy Micro-Arc Alloying Process. Journal of Power Source, 171, 778-782.

[8] Cho, Y.K., Jang, W.S., Yoo, S., Kim, S.G. and Kim, S.W. (2008) Synthesis of Conductive Ti-C:H Films on the Stainless Steel Plates by PECVD Process. Surface and Coatings Technology, 202, 5390-5394.

[9] Liepack, H., Bartsch, K., Arnold, B., Bauer, H.-D., Liu, X., Knupfer, M. and Leohardt, A. (2004) Characteristics of Excess Carbon in PACVD TiC-Amorphous Carbon Layers. Diamond and Related Materials, 13, 106-110.

[10] Caschera, D., Federici, F., Kaciulis, S., Pandolfi, L., Cusma, A. and Padeletti, G. (2007) Deposition of Ti-Containing Diamond-Like Carbon (DLC) Films by PECVD Technique. Materials Science and Engineering C, 27, 1328-1330.

[11] Vetter, J., Burgmer, W. and Perry, A.J. (1993) Arc-Enhanced Glow Discharge in Vacuum Arc Machines. Surface and Coatings Technology, 59, 152-155.

[12] Chang, Y.-Y. and Wang, D.-Y. (2005) Structural and Electrical Properties of Nitrogen-Doped Cr-C:H Films Synthesized by a Cathodic-Arc Activated Deposition Process. Thin Solid Films, 485, 1-7.

[13] Chang, Y.-Y., Wang, D.-Y. and Wu, W.T. (2003) Characterization of NitrogenDoped a-C:H Films Deposited by Cathodic-Arc Activated Deposition Process. Diamond and Related Materials, 12, 2077-2082.

[14] Scharf, T.W., Ott, R.D., Yang, D. and Barnard, J.A. (1999) Structural and Tribological Characterization of Protective Amorphous Diamond-Like Carbon and Amorphous $\mathrm{CN}_{x}$ Overcoats for Next Generation Hard Disks. Journal of Applied Physics, 85, 3142 .

[15] Pal, S.K., Jiang, J. and Meletis, E.I. (2007) Effects of N-Doping on the Microstructure, Mechanical and Tribological Behavior of Cr-DLC Films. Surface and Coatings Technology, 201, 7917-7923.

[16] Robertson, J. (2002) Diamond-Like Amorphous Carbon. Materials Science and Engineering $R, 37,129-281$.

[17] Ferrari, A.C. and Robertson, J. (2000) Interpretation of Raman Spectra of Disordered and Amorphous Carbon. Physical Review B, 61, Article ID: 14095.

https://doi.org/10.1103/PhysRevB.61.14095 
[18] Ferrari, A.C. (2002) Diamond and Related Materials, 11, 440.

[19] Wierzchon, T., Ulbin-Pokorska, I. and Sikorski, K. (2000) Corrosion Resistance of Chromium Nitride and Oxynitride Layers Produced under Glow Discharge Conditions. Surface and Coatings Technology, 130, 274-279.

Submit or recommend next manuscript to SCIRP and we will provide best service for you:

Accepting pre-submission inquiries through Email, Facebook, LinkedIn, Twitter, etc. A wide selection of journals (inclusive of 9 subjects, more than 200 journals)

Providing 24-hour high-quality service

User-friendly online submission system

Fair and swift peer-review system

Efficient typesetting and proofreading procedure

Display of the result of downloads and visits, as well as the number of cited articles Maximum dissemination of your research work

Submit your manuscript at: http://papersubmission.scirp.org/

Or contact ampc@scirp.org 